\title{
Vibrio の血球凝集反応について
}

\author{
木 村 正 健 \\ 横浜検疫所（所長 : 三浦光, 指導 : 東邦大学医学部教授 : 桑原章吾)
}

[受付：6月 10 日，1966 年]

非溶血性エルトール菌1,2,3)の出現にともない，エルト ール菌とコレラ菌の鑑別は Greig 法いないしその変法5, 6)による溶血性の有無だけでは不可能となり，他に種々 の鑑別法7,8) が試みられているが, 現在のところ, 溶血 性の他に Mukerjee のファージIV 感受性9), ポリミキシ ンB感受性 ${ }^{10)}$ とともに Finkelstein らが実用化したニワ トリの赤血球（以下血球と略す）凝集性 ${ }^{11)}$ が重要な鑑別 法に挙げられている。

ところがニワトリ血球スライド凝集反応でコレラ菌に 陽性株を認めるという報告 ${ }^{12,13)}$ もあり, 著者ら ${ }^{14)}$ も追試 の結果, コレラ菌の保存株の一部に陽性例を認め, さら に原法では凝集不明膫で肉眼判定が困難なばあいが多い 欠点のあることを知り, 血球浮遊液として生理食塩液の かわりに $\mathrm{Ca}, \mathrm{Mg}$ 含有 $\mathrm{PBS}(\mathrm{pH} 7.6)$ にすると凝集が 明瞭となり肉眼判定が容易であることを確かめた。その 後さらに各種要素について原法を再検討するとともに， コレラ菌の継代保存にともなう凝集性の変動, 集落変異 との関連性 さらに NAG ビブリオおよび腸炎ビブリオ の血球凝集能について検討したので，そのあらましをま とめてみた。

\section{実跧方法}

\section{I ）使用菌株}

エルトール菌として 1952 年以降 分離された溶血株お よび非溶血株 128 株，コレラ菌は 1952 年以降分離株 33 株, NAG ビブリオとして 1962 年以降分離の 7 株, $V$. parahaemolyticus として 1964 年分離株 6 株, V. alginolyticus として 1963 年以降分離された 6 株を用いた。 とくにエルトール菌ではアロンソン培地で淡紅色集落を つくる株（ピンク株）と樑紅色集落をつくる株（レッ ド株）を併用しピンク株には Rugose 変異株をも含め た。

これらの菌株のうちコレラ菌 および NAG ビブリオ の一部は国立予研より分譲をうけ，V. parahaemolyticus および $V$. alginolyticus は都立衛研より 分譲され
たものである。その内訳は表 1 (a. b) のとおりである。 なお当室保存のコレラ菌およびエルトール菌のうち前 回の実験および今回の実験にも用いた菌株のその間の保 存は半流動カンテン（バクトトリプトーン-Difco 1\%, $\mathrm{NaCl} 0.5 \%$ ，バクトカンテン-Difco $0.5 \%, \mathrm{pH} \mathrm{7.2)}$ にせん刺培養後密封保存し, 継代は 2 力月毎に行なつ, た。

II）実験材料

1）血球浮遊液および菌浮遊液

イ) $\operatorname{PBS}(\mathrm{I})^{15)} \cdots \mathrm{S} \phi$ rensen のリン酸緩衝液 $(\mathrm{A}$ 液 $・ M /$ $15 \mathrm{Na}_{2} \mathrm{HPO}_{4}$ 液, $\mathrm{B}$ 液・ $\mathrm{M} / 15 \mathrm{KH}_{2} \mathrm{PO}_{4}$ 液) で所要 $\mathrm{pH}$ の緩衝液をつくり，本液 1 容に生理食塩液 4 容を加え滅 菌後供試した。

口) $\mathrm{PBS}(\mathrm{II})^{15} \cdots$ A 液) $\mathrm{NaCl} 8.0 \mathrm{~g}, \mathrm{KCl} 0.2 \mathrm{~g}, \mathrm{Na}_{2}$ $\mathrm{HPO}_{4} 1.15 \mathrm{~g}, \mathrm{KH}_{2} \mathrm{PO}_{4} 0.2 \mathrm{~g}$, 精製水 $800 \mathrm{ml}$. B液) Ca: $\mathrm{Cl}_{2} \cdot 2 \mathrm{H}_{2} \mathrm{O} 0.1 \mathrm{~g}$, 精製水 $100 \mathrm{ml}$. C液) $\mathrm{MgCl}_{2} \cdot 6 \mathrm{H}_{2} \mathrm{O}$ $0.1 \mathrm{~g}$, 精製水 $100 \mathrm{ml}$ をそれぞれ滅菌し，用に臨みA液)， 8 容 : B液) 1 容 : C 液) 1 容の割合に混合した。また PBS (II) の各液の血球凝集におよぼす影響を検討した際 はA液） 8 容: B，C 液）のかわりに精製水 2 容を加え， A液） 8 容：B液） 1 容：C液）のかわりに精製水 1 容 を加え，またA液） 8 容：C液）1容：B液）にかえて 精製水 1 容を加えた各種の組合せで比較検討した。

八) 滅菌生理食塩液

2) 血球・ウシ，ウマ，メンョウ，ウサギ，モルモッ ト, ニワトリ（使用時に Alseber 液保存血を PBS ない し生理食塩液で洗浄した。)

III）検查方法および判定

スライド上にツ反応用注射器で カンテン培地 20 時間 培養菌の菌液 1 滴と血球液 1 滴を落とし, 混合後 5 分間 振盪しながら観察し, 凝集の有無を肉眼で判定した。判 定基準は下記によつた。

一 : 非凝集, \pm : 凝集不明瞭, + : 5 分で㠜集, $H$ : 3 分以内に凝集, $\#: 1$ 分以内に凝集, 册 : 30秒以内で 凝集 
表 $1 \mathrm{a}$ 使用䧠株

\begin{tabular}{|c|c|c|c|c|c|c|c|c|c|}
\hline 菌 & 数 & 分離年次 & 分離 地 & 菌 株 & 数 & 分離年次 & 分 & 離 & 地 \\
\hline \multirow{4}{*}{ V. e. } & 4 & 1952 & $\left\{\begin{array}{l}\text { バンコック } \\
\text { マカッサル }\end{array}\right.$ & \multirow{5}{*}{ V. c. } & 10 & 1952 & 1 & ン & ド \\
\hline & 2 & 1960 & ウボール & & 8 & 1957 & バン & ב & 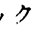 \\
\hline & 11 & 1961 & セレベス & & 4 & 1958 & & $\prime \prime$ & \\
\hline & 111 & 1964 & フィリピン & & 10 & 1961 & 1 & ン & ド \\
\hline \multirow{3}{*}{ NAG V. } & 3 & 1962 & & & & 1903 & 河 & 口 & 湖 \\
\hline & 1 & 1963 & II & \multirow{3}{*}{ V. a. } & 1 & 1963 & 東 & & 京 \\
\hline & 3 & 1964 & フィリピン & & 4 & 1964 & & $\prime \prime$ & \\
\hline V. p. & 6 & 1964 & 東 & & & & & & \\
\hline
\end{tabular}

b 基礎実験使用菌株

\begin{tabular}{|c|c|c|c|c|c|c|c|}
\hline 菌 & 株 & 溶血 & $\begin{array}{l}\text { アロンソン } \\
\text { 培地集落 }\end{array}$ & 菌 & 株 & 溶血 & $\begin{array}{l}\text { アロンソン } \\
\text { 培地集落 }\end{array}$ \\
\hline \multirow{10}{*}{$\begin{array}{l}\text { V. e. } \\
10 \text { 株 }\end{array}$} & B 1858 & - & $\mathrm{P}$ & \multirow{3}{*}{$\begin{array}{l}\text { V. c. } \\
3 \text { 株 }\end{array}$} & 114 & - & $\mathrm{R}$ \\
\hline & B 1903 & - & $\mathrm{P}$ & & 122 & - & $\mathrm{R}$ \\
\hline & B 1327 & - & $\mathrm{P}(\mathrm{Ru})$ & & WLL & - & $\mathrm{R}$ \\
\hline & D 4040 & - & $P \cdot(R u)$ & \multirow{6}{*}{$\underset{5}{\text { NAG V. }}$} & 5357 & & $\mathrm{P}$ \\
\hline & D 4257 & - & $\mathrm{P}(\mathrm{Ru})$ & & 8560 & & $\mathrm{P}$ \\
\hline & В 1697 & - & $\mathrm{R}$ & & 7046 & & $\mathrm{R}$ \\
\hline & B 1811 & - & $\mathrm{R}$ & & $\mathrm{K} 42$ & & $\mathrm{P}$ \\
\hline & B 1901 & + & $\mathrm{R}$ & & Q24 & & $P$ \\
\hline & В 934 & + & $\mathrm{R}$ & & & & \\
\hline & В 3352 & + & $\mathrm{R}$ & \multirow{3}{*}{$\begin{array}{l}\text { V. p. } \\
3\end{array}$} & Т 1264 & & W \\
\hline \multirow{5}{*}{$\begin{array}{c}\text { V. c. } \\
4 \text { 株 }\end{array}$} & 90 & - & $\mathrm{R}$ & & $\mathrm{T} 1306-1$ & & $\begin{array}{l}\text { W } \\
W\end{array}$ \\
\hline & 91 & - & $\mathrm{R}$ & & & & \\
\hline & 120 & - & $\mathrm{R}$ & \multirow{3}{*}{$\begin{array}{l}\text { V. a. } \\
3 \text { 株 }\end{array}$} & $C-15$ & & $\mathrm{R}$ \\
\hline & 120 & - & $\mathrm{R}$ & & T 1294-1 & & $\mathrm{R}$ \\
\hline & & & & & T $132 \varepsilon$ & & $\mathrm{R}$ \\
\hline
\end{tabular}

V.e. : V. eltor, V.c. : V. cholerae, NAG V. : NAG Vibrio V.p. : V. parahaemolyticus, V.a. : V. alginolyticus $\mathrm{P}$ : 淡紅色, $\mathrm{R}$ : 深紅色, $\mathrm{W}$ : 白色, Ru : Rugose 集落以下各表上 も同じ. V.e : フィリピン分離の 111 株には 108 株の非溶血株を含む, その他は溶血株

\section{IV) SR 変異の鑑別法}

コレラ菌 R 型抗血清（横浜検変所横須賀支所長浜野満 雄博士より分譲されたもの）によるスライド凝集反応， ミロン反応および $0.1 \%$ \%アリフラビン液によるスライ ド凝集反応によつて鑑別した。

\section{実験成縤}

\section{1) 血球の種類と浮遊液 $\mathrm{pH}$ の検討}

$\mathrm{pH} \mathrm{6，7および} 8$ に調製した PBS（I）を浮遊液にし てそれぞれ $2.5 \%$ 血球液および $10 \mathrm{mg} / \mathrm{ml}$ 菌液をつくつ て反応を行なつた成績は表 2 のとおり，エルトール菌は 全株陽性, コレラ菌は 7 株中 2 株陽性, NAG ビブリオ
は 5 株中 3 株陽性, V. parahaemolyticus およびV. alginolyticus は 3 株中 1 株陽性であつたが，陽性株の 反応は $\mathrm{pH} 6$ 以下ではよわく，7および 8 では凝集が明 瞭となつた。また血球ではモルモットが最も感受性鋭敏 で，ウサギ，ウマおよびニワトリはほぼ同程度の感受性 でモルモットに次ぎ，メンヨウはそれらより劣り，ウシ では最もよわい反応を示した。

2) PBS の種類の検討

$\mathrm{pH} 7.6$ に調製した PBS（I)と PBS（II）の（A液十 精製水)，（A液+ B 液+精製水），（A液+ C 液+精製 水)，( $\mathrm{A}$ 液 $+\mathrm{B}$ 液 $+\mathrm{C}$ 液）の各組合せを浮遊液にして血 球浱度 $2.5 \%$, 菌量 $10 \mathrm{mg} / \mathrm{ml}$ として反応を行なつた結 
表 2 血球の程類と浮遊液 $\mathbf{p H}$ の凝集におよぼす影響

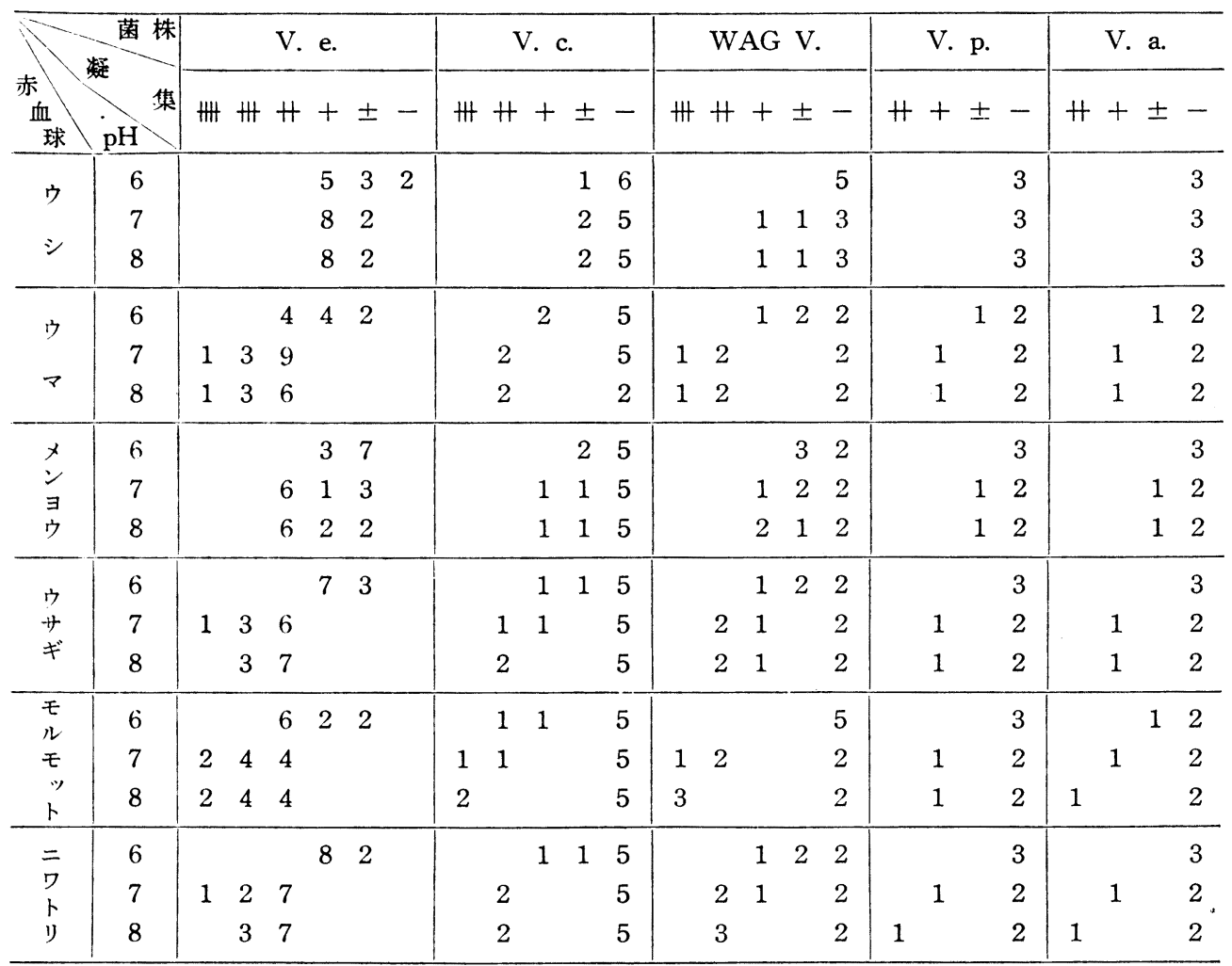

数字は菌株数，以下各表とも同じ

果, 表 3 のとおり,どの血球種のばあいもA液+ B液+精 製水および $\mathrm{A}$ 液＋B液＋C液を浮遊液にしたばあいが， $\mathrm{A}$ 液 $+\mathrm{C}$ 液十精製水， $\mathrm{A}$ 液十精製水および $\mathrm{PBS}(\mathrm{I})$ を 浮遊液にしたばあいよりも，凝集陽性株の凝集に要する 時間が短縮される菌株が多くなつた。つまり PBS(I) よりも $\mathrm{Ca}(\mathrm{Mg})$ を加えた $\mathrm{PBS}(\mathrm{II})$ が反応用浮遊液に好 適であることがわかり，Ca イオンは反応を促進させる ことが羿められた。

\section{3）菌濃度および血球濃度の検討}

PBS（II）を浮遊液にして血球浱度 $1.5 ， 2.5 ， 5$ およ び $10 \%$ の血球液と菌量 $5,10,20$ および $40 \mathrm{mg} / \mathrm{ml}$ の 菌液をつくり反応を行なつたところ，表 4 のとおり，凝 集陽性株はどの血球種のばあいも $2.5 \%$ と $5 \%$ とではと くに反応の強弱に差を認めなかつたが，判定の容易さか らみると $5 \%$ のばあいが血球凝集塊も多くて判定しやす く，また $1.5 \%$ \% $10 \%$ では反応がみにくかつた。菌量 では $20 \mathrm{mg} / \mathrm{ml}$ のばあいに較べて $10 \mathrm{mg} / \mathrm{ml}$ 以下では反 応がおそく凝集が低下する傾向を示し，また $40 \mathrm{mg} / \mathrm{ml}$ にしても $20 \mathrm{mg} / \mathrm{ml}$ のばあいと反応に差を認めなかつ
た。したがつて血球濃度は $5 \%$ ていど，菌量 $20 \mathrm{mg} / \mathrm{ml}$ ぐらいが反応に適当であることが認められた。

なおメンョウ血球では血球濃度および菌量を変えても ニワトリ血球よりを反応がよわかつた。

\section{4) 検査方法の検討}

以上の実験成績からスライド上で $\mathrm{PBS}$ (II) 1 滴にカ ンテン培地 20 時間培養菌の $20 \mathrm{mg} / \mathrm{ml}$ 相当菌量, 約 1 白金耳量を均等に浮遊し，さらに $5 \%$ 血球液（モルモッ ト，ウサギおよびニワトリ） 1 滴を滴下混合する変法と $3 \%$ 血球液 1 滴に $10 \mathrm{mg} / \mathrm{ml}$ 相当菌量(粟粒大の菌塊)を 白金耳にとり，直接混合する便法で反応を行ない比較し た結果, 両法ともエルトール菌はじめ凝集陽性株はす心゙ て肉眼で明暸にわかる凝集を示し, Rugose 変異を起し たエルトール菌株の集落でも便法で実施可能であり,さ らに便法で反応を行なつたばあいに凝集陽性株の反応が 速く出現する傾向が認められた。

5）培地の種類と培㙿時間の凝集能におよぼす影響 アロンソン培地, TSI カンテン, クリグラー培地お よびカンテン培地にエルトール菌, コレラ菌, NAG ビ 


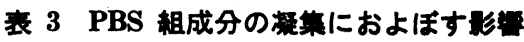

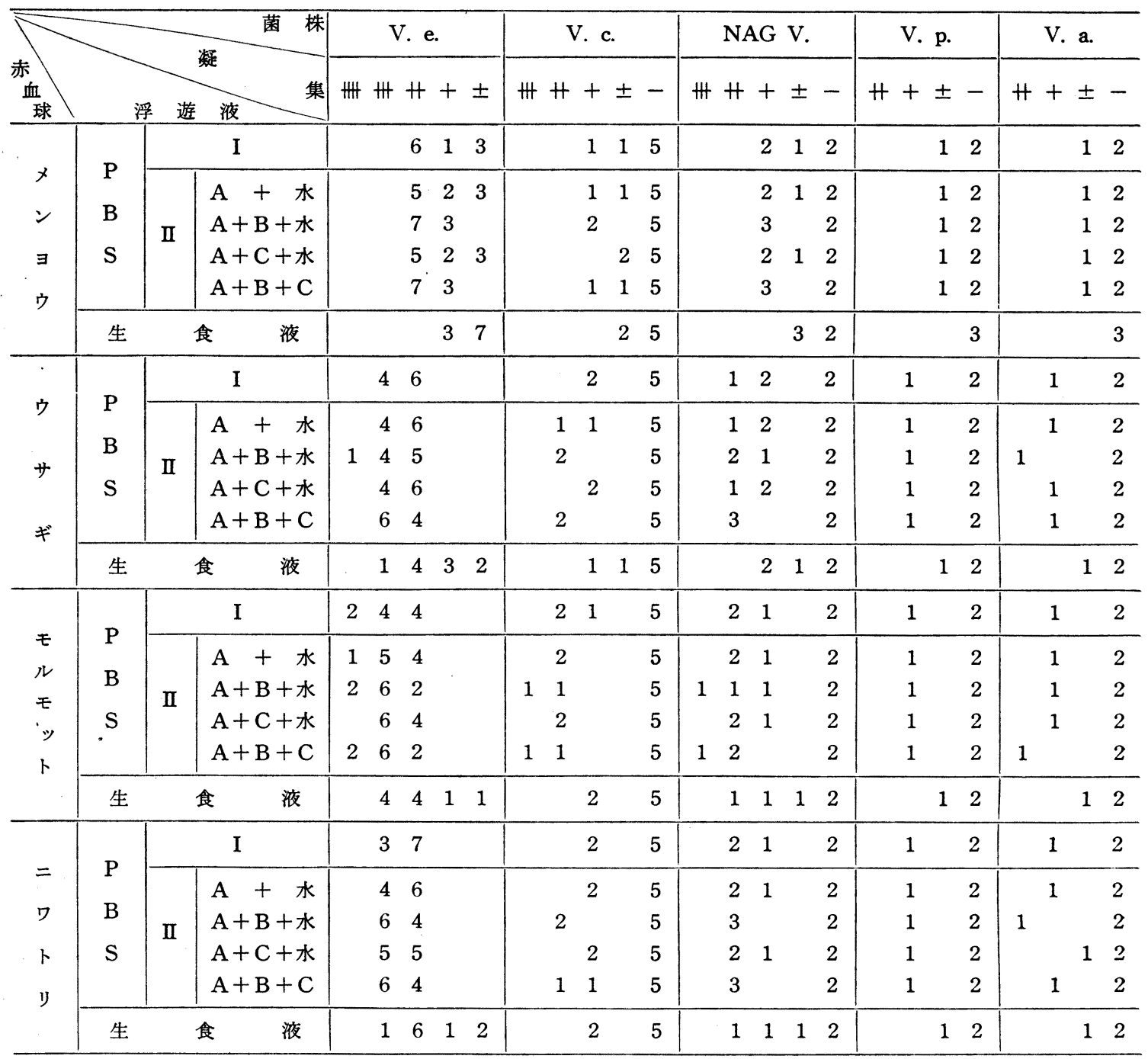

生食液：生理食塩液

ブリオ, V. parahaemolyticus および $V$. alginolyticus を培養後 24 時間毎に便法で反応を行なつた 結果は表 5 のとおり，アロンソン培地で淡紅色集落をつくるエルト 一ル菌のピンク株, NAG ビブリオの一部菌株および白 色集落をつくる $V$. parahaemolytcus では どの培地で も培養 96 時間後も凝集陽性株の反応低下はほとんど認 められなかつた。アロンソン培地に樑紅色集落をつくる エルトール菌のレッド株, コレラ菌, NAG ビブリオの 一部菌株および $V$. alginolyticus ではクリグラ一培地 およびカンテン培地に培養したばあいは 96 時間後も凝 集陽性株の反応はほとんど低下しなかつたが，アロンソ
ン培地および TSI カンテンでは培養 12 時間後すでに凝 集の低下が認められ，24 時間以後では凝集しなくなつ た。

これらの培地の培養 24 時間以後の $\mathrm{pH}$ を測つてみる と, アロンソン培地で淡紅色ないし白色集落形成菌株群 ではいずれの培地表面集落部とも 8 以上を示したのに対 して, 深紅色集落形成菌株群ではクリグラ一培地および カンテン培地表面集落は 8 以上を示したが, TSI カンテ ンおよびアロンソン培地表面集落部では 6 以下を示し, ビブリオの血球凝集能は $\mathrm{pH} 6$ 以下では働らかなくなる ことが認められた。 


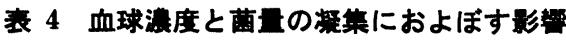

\begin{tabular}{|c|c|c|c|c|c|c|c|c|c|c|c|c|c|c|c|c|c|c|c|c|c|}
\hline \multirow{2}{*}{\multicolumn{3}{|c|}{$\begin{array}{ll}\text { 赤 } & \text { 菌 } \\
\text { 血 } \\
\text { 球 } \% & \text { 菌量 } \\
\end{array}$}} & \multicolumn{5}{|c|}{ V. e. } & \multicolumn{4}{|c|}{ V. c. } & \multicolumn{4}{|c|}{ NAG V. } & \multicolumn{3}{|c|}{ V. p. } & \multicolumn{3}{|c|}{ V. a. } \\
\hline & & & & W & H & H & + \pm & m & H & + & - & m & $H$ & + & - & $H$ & $+=$ & - & $H$ & + & - \\
\hline \multirow{6}{*}{$\begin{array}{l}メ \\
\text { ン } \\
\exists \\
\text { ウ }\end{array}$} & \multirow{3}{*}{2.5} & 5 & & & & & 64 & & & 2 & 5 & & & 3 & 2 & & & 3 & & & 3 \\
\hline & & 10 & & & & 7 & 3 & & & 2 & 5 & & & 3 & 2 & & 1 & 2 & & 1 & 2 \\
\hline & & 20 & & & & 8 & 2 & & & 2 & 5 & & & 3 & 2 & & 1 & 2 & & 1 & 2 \\
\hline & \multirow{3}{*}{5} & 10 & & & & 7 & & & & 2 & 5 & & & 3 & 2 & & 1 & 2 & & 1 & 2 \\
\hline & & 20 & & & & 9 & 1 & & & 2 & 5 & & 1 & 2 & 2 & & 1 & 2 & & 1 & 2 \\
\hline & & 40 & & & & & 1 & & & 2 & 5 & & 1 & 2 & 2 & & 1 & 2 & & 1 & 2 \\
\hline \multirow{3}{*}{ ウ } & \multirow{3}{*}{2.5} & 5 & & & 2 & 8 & & & 1 & 1 & 5 & & 1 & 2 & 2 & & 1 & 2 & & 1 & 2 \\
\hline & & 10 & & & 7 & 3 & & & 2 & & 5 & & 2 & 1 & 2 & & 1 & 2 & & 1 & 2 \\
\hline & & 20 & & 1 & 8 & 1 & & & 2 & & 5 & & 3 & & 2 & & 1 & 2 & & 1 & 2 \\
\hline+ & \multirow{3}{*}{5} & 10 & & & 7 & 3 & & & 2 & & 2 & & 2 & 1 & 2 & & 1 & 2 & & 1 & 2 \\
\hline \multirow[t]{2}{*}{ ギ } & & 20 & & 2 & 8 & & & 1 & 1 & & 2 & & 3 & & 2 & & 1 & 2 & & 1 & 2 \\
\hline & & 40 & & 2 & 8 & & & 1 & 1 & & 2 & & 3 & & 2 & & 1 & 2 & & 1 & 2 \\
\hline \multirow{6}{*}{$\begin{array}{l}モ \\
ル \\
モ \\
\% \\
ト\end{array}$} & \multirow{3}{*}{2.5} & 5 & & & 3 & 7 & & & 1 & 1 & 5 & & 2 & 1 & 2 & & 1 & 2 & & 1 & 2 \\
\hline & & 10 & & 2 & 6 & 2 & & 1 & 1 & & 5 & 1 & 1 & 1 & 2 & & 1 & 2 & & 1 & 2 \\
\hline & & 20 & & 3 & 6 & 1 & & 1 & 1 & & 5 & 1 & 2 & & 2 & & 1 & 2 & & 1 & 2 \\
\hline & \multirow{3}{*}{5} & 10 & & 2 & 5 & 3 & & 1 & 1 & & 5 & 1 & 2 & & 2 & & 1 & 2 & & 1 & 2 \\
\hline & & 20 & & 3 & 7 & & & 2 & & & 5 & 2 & 1 & & 2 & 1 & & 2 & 1 & & 2 \\
\hline & & 40 & & 3 & 7 & & & 2 & & & 5 & 2 & 1 & & 2 & 1 & & 2 & 1 & & 2 \\
\hline \multirow{6}{*}{$\begin{array}{l}= \\
ワ \\
ト \\
\text { リ }\end{array}$} & \multirow{3}{*}{2.5} & 5 & & & 2 & 8 & & & 2 & & 5 & & 1 & 2 & 2 & & 1 & 2 & & 1 & 2 \\
\hline & & 10 & & & 6 & 4 & & 1 & 1 & & 5 & & 1 & 2 & 2 & & 1 & 2 & & 1 & 2 \\
\hline & & 20 & & 1 & 8 & 1 & & 1 & 1 & & 5 & 1 & 2 & & 2 & & 1 & 2 & 1 & & 2 \\
\hline & \multirow{3}{*}{5} & 10 & & & 8 & 1 & & & 2 & & 5 & 1 & 1 & 1 & 2 & & 1 & 2 & & 1 & 2 \\
\hline & & 20 & & 2 & 7 & 1 & & 1 & 1 & & 5 & 1 & 2 & & 2 & 1 & & 2 & 1 & & 2 \\
\hline & & 40 & & 2 & 8 & & & 1 & 1 & & 5 & 1 & 2 & & 2 & 1 & & 2 & 1 & & 2 \\
\hline
\end{tabular}

菌量は $\mathrm{mg} / \mathrm{ml}$ 量を示す

\section{6）便法と原法の比較}

便法と原法による反応成績は表 6 に示すとおりであつ て，エルトール菌ではいずれの方法でも溶血の有無に関 係なく 128 株全株が 陽性であつたが，原法では 24 株が 反応がよわく，そのうち 1 株は肉眼判定が不可能であつ たのに反して，便法では大多数が $1 \sim 2$ 分以内に凝集 し， 3 分以内に全株が明瞭な凝集を示した。コレラ菌で は 15 株が陽性, 8 株は陰陽集落の 混在株であり, 10 株 が陰性で，成績そのものは両法とも一致したが，陽性株 中 5 株が原法では肉眼判定ができなかつたのに対して， 便法では全陽性株が明確な凝集を認めた。NAG ビブリ オでは 7 株中 5 株, V. parahaemolyticus および $V$. alginolyticus では 6 株中 2 株が陽性で，便法では明瞭 に凝集を示したのに対して, 原法では凝集不明瞭な例数 が多かつた。

血球種ではモルモットを用いたばあいが最も強陽性例 数が多く，ニワトリではウサギとほぼ同等でこれに次い だ。

7）コレラ菌の継代保存による凝集能の変動と SR 変 異との関連性

分離年次をほぼ同一にするコレラ菌 16 株とエルトー ル菌 76 株を 継代保存し, 1 年余経過後カンテン培地に 劃線培養し，前回同様に約 20 個の集落について便法で 反応を行ない, 凝集能の変動をしらべたところ, 表 7 に 


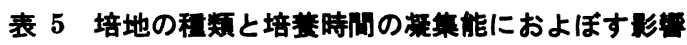

\begin{tabular}{|c|c|c|c|c|c|c|c|c|c|}
\hline \multirow{3}{*}{$\overbrace{\text { 株 }}$} & \multirow{3}{*}{ 培地 } & \multirow{3}{*}{$\begin{array}{c}\text { ア } \\
122496\end{array}$} & \multirow{2}{*}{$\begin{array}{l}\text { ソン } \\
\text { 集 落 }\end{array}$} & \multirow{3}{*}{122496} & \multirow{2}{*}{$\begin{array}{ll}\text { I } & \text { S } \\
\text { 培 } & \text { 地 }\end{array}$} & \multirow{3}{*}{122496} & グ ラ - & \multicolumn{2}{|c|}{ カンテン } \\
\hline & & & & & & & 培 & & 集落 \\
\hline & & & $\mathrm{pH}$ 色 & & $\mathrm{pH}$ & & $\mathrm{pH}$ & 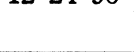 & $\mathrm{pH}$ \\
\hline \multirow{2}{*}{ V. e. } & 5 & 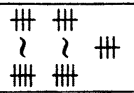 & $8.4 \mathrm{P}$ & 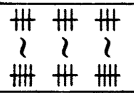 & $8.2 / 6.2 \mathrm{R} / \mathrm{Y}$ & 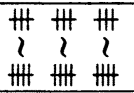 & $8.2 / 6.2 \mathrm{R} / \mathrm{Y}$ & 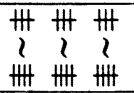 & 8.2 \\
\hline & 5 & $\begin{array}{l}+\bar{r}- \\
i+ \\
++\end{array}$ & $5.6 \mathrm{R}$ & W $\begin{array}{l}+ \\
\text { I }\end{array}$ & $5.8 / 5.6 \mathrm{Y} / \mathrm{Y}$ & 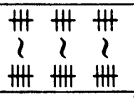 & $8.2 / 6.2 \mathrm{R} / \mathrm{Y}$ & 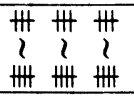 & 8.2 \\
\hline \multirow{2}{*}{ V. c. } & 2 & $H--$ & $5.6 \mathrm{R}$ & $H+-$ & $5.8 / 5.6 \mathrm{Y} / \mathrm{Y}$ & $H H H$ & $8.0 / 6.0 \mathrm{R} / \mathrm{Y}$ & $H H H$ & 8.0 \\
\hline & 5 & --- & $5.6 \mathrm{R}$ & --- & $5.6 / 5.6 \mathrm{Y} / \mathrm{Y}$ & --- & $8.0 / 6.0 \mathrm{R} / \mathrm{Y}$ & --- & 8.0 \\
\hline \multirow{3}{*}{$\begin{array}{l}\mathrm{N} \\
\mathrm{A} \\
\mathrm{G} \\
\mathrm{V}\end{array}$} & 2 & $\sum_{H}^{H} H+H$ & $8.2 \quad \mathrm{P}$ & $\begin{array}{ccc}H & H & \# \\
2 & 2 & 2 \\
m & m & \text { H } \\
\end{array}$ & $8.2 / 6.2 \mathrm{R} / \mathrm{Y}$ & $\begin{array}{ccc}H & H & H \\
2 & 2 & \sim \\
m & m & \text { m } \\
\end{array}$ & $8.0 / 6.0 \mathrm{R} / \mathrm{Y}$ & $\begin{array}{ccc}H & H & H \\
2 & 2 & 2 \\
m & m & \text { m } \\
\end{array}$ & 8.0 \\
\hline & 1 & $m+-$ & $5.8 \mathrm{R}$ & m + - & $6.0 / 5.6 \mathrm{Y} / \mathrm{Y}$ & W $\#$ \# & $8.2 / 6.2 \mathrm{R} / \mathrm{Y}$ & m $\#$ H & 8.0 \\
\hline & 2 & --- & $8.2 \mathrm{P}$ & --- & $8.0 / 6.0 \mathrm{R} / \mathrm{Y}$ & --- & $8.2 / 6.0 \mathrm{R} / \mathrm{Y}$ & --- & 8.0 \\
\hline \multirow{2}{*}{ V. p. } & 1 & ++ \pm & $8.0 \mathrm{~W}$ & ++ \pm & $8.0 / 6.2 \mathrm{R} / \mathrm{Y}$ & ++ \pm & $8.0 / 6.0 \mathrm{R} / \mathrm{Y}$ & ++ \pm & 8.0 \\
\hline & 2 & --- & $8.0 \mathrm{~W}$ & --- & $8.0 / 6.0 \mathrm{R} / \mathrm{Y}$ & --- & $8.0 / 6.0 \mathrm{R} / \mathrm{Y}$ & --- & 8.0 \\
\hline \multirow{2}{*}{ V. a. } & 1 & --- & $5.8 \mathrm{R}$ & --- & $5.8 / 5.6 \mathrm{Y} / \mathrm{Y}$ & +++ & $8.0 / 6.2 \mathrm{R} / \mathrm{Y}$ & $H+H+$ & 8.0 \\
\hline & 2 & --- & $5.8 \mathrm{R}$ & --- & $5.8 / 5.6 \mathrm{Y} / \mathrm{Y}$ & --- & $8.0 / 6.0 \mathrm{R} / \mathrm{Y}$ & --- & 8.0 \\
\hline
\end{tabular}

冊 ー : 凝集, 使用赤血球 : モルモット, ウサギ, ニワトリ, 培地色の R は紅色, $\mathrm{Y}$ は黄色を示す

表 6 便法と原法による反応成椟の比较

\begin{tabular}{|c|c|c|c|c|c|c|c|c|c|c|c|c|c|c|}
\hline \multirow{3}{*}{\multicolumn{2}{|c|}{ 菌 赤 血 }} & \multicolumn{5}{|c|}{ 便 } & \multicolumn{4}{|c|}{ 法 } & \multicolumn{2}{|c|}{ 原 } & \multicolumn{2}{|r|}{ 法 } \\
\hline & & & モ & & ウ & サ & ギ & $=$ & ワ & リ & $=$ & ワ & r & リ \\
\hline & & $\uparrow H$ & + & - & $\uparrow H$ & + & - & $\uparrow H$ & + & - & $\uparrow H$ & + & \pm & - \\
\hline V. e. & 128 & 128 & & & 128 & & & 128 & & & 104 & 23 & 1 & \\
\hline V. c. & 33 & $14(8)$ & 1 & $10(8)$ & $11(6)$ & $4(2)$ & $10(8)$ & $10(6)$ & $4(2)$ & $10(8)$ & $8(4)$ & $2(4)$ & 5 & $10(8)$ \\
\hline NAG V. & 7 & 5 & & 2 & 5 & & 2 & 5 & & 2 & 2 & 1 & 2 & 2 \\
\hline V. p. & 6 & & 2 & 4 & & 2 & 4 & & 2 & 4 & & & 2 & 4 \\
\hline V. a. & 6 & & 2 & 4 & & 2 & 4 & 1 & 1 & 4 & & & 2 & 4 \\
\hline
\end{tabular}

$\uparrow+\mathrm{H}: 30$ 秒〜 3 分以内に凝集, （）：同一株に陰陽集落が混在した株数

示すとおり，エルトール菌は 1964 年も1965 年も全株陽 性で凝集能の変動はまつたく認められなかつたが，コレ ラ菌では 1964 年 8 月陰性であつた 16 株のうち 1965 年 9 月には完全に陽性化したもの 5 株, 陰, 陽集落の混在 したもの 8 株が出現し, コレラ菌は継代保存中に凝集陽 性化するものがあることを認めた。

次に血球凝集性が完全に陰性もしくは陽性であつたコ レラ菌 19 株について, その凝集の陰陽と SR 変異との 関連性をしらべてみると, 表 8 のとおり, 凝集陽性でも
$\mathrm{R}$ 型変異を認めないもの 5 株, また凝集陰性でも $\mathrm{R}$ 型変 異を認めたもの 5 株を示し, 凝集の陰陽が SR 変異とと くに関連性がないことがわかつた。

のせガラス法による血球凝集性の有無によつて, エル トール菌とコレラ菌を鑑別する方法は, Barua ら ${ }^{16)}$ がメ ンヨウ, ウサギ, ヒトおよびニワトリの血球を使つてそ の可能性を認め, Finkelstein ら¹) がニワトリ血球を用 
表 7 コレラ菌の綎代保存による凝集性の変趵

\begin{tabular}{|c|c|c|c|c|c|}
\hline \multirow{2}{*}{\multicolumn{3}{|c|}{ 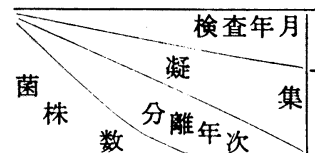 }} & $1964 \mathrm{VII}$ & \multirow{2}{*}{$\frac{1965}{+}$} & \multirow[t]{2}{*}{ IX } \\
\hline & & & +- & & \\
\hline \multirow{4}{*}{ V.e. } & 4 & 1952 & 4 & 4 & \\
\hline & 2 & 1960 & 2 & 2 & \\
\hline & 11 & 1961 & 11 & 11 & \\
\hline & 59 & 1964 & 59 & 59 & \\
\hline \multirow{4}{*}{ V. c. } & 2 & 1952 & 2 & 1 & 1 \\
\hline & 3 & 1957 & 3 & 2 & 1 \\
\hline & 10 & 1961 & 10 & $2(8)$ & $2(8)$ \\
\hline & 1 & 1963 & 1 & & 1 \\
\hline
\end{tabular}

（ ）内の数字は同一株に陰，陽集落が混在した株数

\section{表 8 コレラ苗の SR 変異と疑集能の閶係}

\begin{tabular}{|c|c|c|c|c|c|}
\hline \multirow{2}{*}{ 菌 } & 株 & \multirow{2}{*}{ 凝 } & \multicolumn{2}{|c|}{ S R 鑑 } & 別 \\
\hline & 分離年次 & & $\begin{array}{l}ミ \\
\text { ロ } \\
\text { ン }\end{array}$ & $\begin{array}{l}\text { アラ } \\
\text { クビ } \\
\text { リン } \\
\text { フ }\end{array}$ & $\begin{array}{l}\mathrm{R} \\
\text { 血 } \\
\text { 清 }\end{array}$ \\
\hline 375 & 1952 & + & + & + & + \\
\hline 384 & "I & - & + & + & + \\
\hline 393 & "I & + & + & + & + \\
\hline 399 & "I & + & - & - & - \\
\hline 420 & $\prime \prime$ & + & + & + & + \\
\hline 368 & $\prime \prime$ & - & - & - & - \\
\hline 378 & $\prime \prime$ & - & + & + & + \\
\hline 425 & $\prime \prime$ & - & - & - & - \\
\hline 556 & $\prime \prime$ & - & + & + & + \\
\hline 558 & $\prime \prime$ & - & + & + & + \\
\hline 95 & 1957 & + & - & - & - \\
\hline 194 & "I & + & - & - & - \\
\hline 218 & $\prime \prime$ & + & + & + & + \\
\hline 761 & "I & + & - & - & - \\
\hline 1073 & "I & + & - & - & - \\
\hline 1192 & "I & - & \pm & \pm & - \\
\hline 1787 & "I & + & + & + & + \\
\hline MAYA 3 & $\prime \prime$ & - & + & + & + \\
\hline WLL & 1963 & - & - & - & - \\
\hline
\end{tabular}

いて実用化した。本反応は診断の迅速性ではその他の鑑 別法より秀れているが，原法で次凝集が不明瞭で肉眼判 定が困難なばあいがある。その主因は血球および菌の浮 遊液（生理食塩液）の $\mathrm{pH}$ にあると考えられる。Barua ら ${ }^{17)}$ は $\mathrm{pH} 6.2$ では凝集が起り，10.2では凝集しなく なると指摘しているが，浮遊液 $\mathrm{pH}$ が酸性に傾くにした
がつて反応が低下し，中性ないし弱アルカリ性では著明 となる傾向が認められるので, 浮遊液の $\mathrm{pH}$ は 7.0 8.0 にしたほうがよく，さらにCa イオンによつて反応が促 進されるため, 浮遊液には組織培養に常用される $\mathrm{Ca}$, $\mathrm{Mg}$ を含む PBS（pH 7.6）を用いたほうがよい。

血球はその種類によつて感受性に差がみられ，モルモ ットが最も感受性高く，ニワトリはウサギおよびウマと 同等でモルモットよりおとる。メンヨウはこれに次ぎ, ウシは最もおとる。Barua ら ${ }^{17)}$ はンョウ，ウサギ，七 トおよびニワトリの血球ではエルトール菌は陽性, コレ ラ菌は陰性であつたが，モルモット血球ではコレラ菌の 一部菌株に陽性例を認めたため，モルモット血球は本反 応に不適当であると指摘しているが，モルモット血球で 凝集を示すコレラ菌株はウサギ，ウマ，ニワトリおよび メンヨウの血球でも, その反応の程度に明らかな強弱差 はあるが，す心゙て凝集を示し，モルモット血球だけを凝 集するコレラ菌株は認められない。Takeya ら ${ }^{122}$ はヤギ の血球も使用できるとしているが，Doorenbos》 は試験 管でモルモットでは凝集を認め，ヤギでは認めていな い。またメンヨウ血球では凝集が微弱なばあいがあり， ウシ血球では凝集がほとんど認められないばあいが多 い。したがつて本反応に使用寸る血球種は最も感受性が 鋭敏なモルモット血球が望ましく，ウサギおよびウマの 血球もニワトリ血球と同等に使用できる。血球濃度は判 定の容易さからみて $2 \sim 2.5 \%$ ていどの濃度より $3 \sim 5$ \%ていどにしたほうがよい。

本反応を行ならばあいの被検菌の培養上考慮すべき条 件としてはカンテン培地ないしクリグラー培地等の培脊 後培地表面部の酸性化を認めない培地を選ぶことが必要 であり，酸性化を示す培地を使用すると，その分解酸に よる $\mathrm{pH}$ 低下のため, Vibrio の血球凝集作用が起らなく なり，判定を誤まるおそれががる。

本反応は前もつて菌液をつくる必要はなく， $3 \%$ 血球 液 1 滴に直接栗粒大の菌塊を挸汼混合すれば, 検查は一 層簡便かつ迅速に肉眼判定ができて実用的である。

本反応でエルトール菌は溶血の有無, 集落の変異, 保 存度に関係なく陽性で，その凝集能は固有の性状と考え

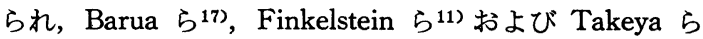
12)の成績と同様であつたが，コレラ菌は SR 変異に関 倸なく，継代保存中に凝集陽性化する 菌株を認め, Takeya ら ${ }^{12)}$ の見解と一致し，したがつてコレラ菌をこの 反応で陰陽 2 型に 類別する Feeley ${ }^{18)}$ の見解には検討の 余地があると考えられる。本反応によるエルトール菌と コレラ菌の鑑別は保存株では困難であり,さらに Bene- 
nson ら ${ }^{13)}$ の報告もあわせ考えると，本反応はポリミキ シンBないしコリスチン感受性試験 ${ }^{10,19)}$, 変法トリプシ ン培地鑑別試験20)よりおとるものと考えられる。しかし ながら本反応で陰性のばあいはコレラ菌と診断しうるの で，鑑別試験としての価値はじゆうぶんあると考える。

NAG ビブリオ, V. parahaemolyticus および V.alginolyticus には陰性株と陽性株の 2 型が認められ，陽 性株の血球凝集作用はエルトール菌および凝集陽性コレ ラ菌株の凝集態度と一致し, 酸に対して抵抗性がなく, 血球種の選択性も同様で Virio の血球凝集現象は 同一 機序によつて起るものと考えられる。Takeya ら ${ }^{12)}$, Burua · 「 ${ }^{17)}$ はエルトール菌の 血球凝集能は加熱および アルコール，ホルマリン等の物理，化学的処理に対する 抵抗性がないことを明らかにし，さらに Takeya ら ${ }^{12)}$ は電顕像で線毛様物質の存在をエルトール菌で観察し， 血球凝集作用が菌体表面構造物によるであろらと示唆し ている。Kraus ら ${ }^{21)}$ ，Fukuhara ${ }^{22)}$ 等によつて 観察され た細菌の 血球凝集反応は Duguid $5^{28,24)}$ の大腸菌, 赤 痢菌についての実験で, 細菌線毛の血球凝集性に起因す ることが明らかにされ，また細菌線毛の最も顕著な特徵 の一つは, モルモットの血球凝集能をもち, その他の動 物の血球に対してもそのていどは低いが同様の作用を有 し，ただウシ血球はほとんど凝集しないこと25)とされて いるが, Vibrio の血球凝集作用はほぼそれと一致した性 状を示す。さらに NAG ビブリオ，V. parahaemolyticus および $V$. alginolyticus の血球凝集陽性株と陰性 株の存在，あるいはコレラ菌の一部菌株の継代保存によ る凝集陽性化現象は Duguid らが解明した ${ }^{25}$ 線毛株と非 線毛株の存在，あるいは線毛株の非線毛形から線毛形へ の変異現象と解釈することができ，前述の血球凝集性状 と考えあわせると Vibrio の血球凝集作用は線毛による のであろらと予想されないこともないが，Barua ら は D-マンノースにによつて 血球凝集性が阻害されない こと，またその他の性状，さらに電顕像で線毛を確認で きなかつたことなどから，酵素作用による凝集を示唆し ている。しかし，目下のところ Vibrio の血球凝集作用 の機序についてはまだ解明されていないようであり，今 後の検討を待たなければ結論つけりるこはできない。

\section{結 睔}

Finkelstein $ら^{10)}$, Barua $ら^{18)}$ の血球凝集反応を再検 討し; 次の結論を得た。

1）血球の浮遊液を $\mathrm{Ca}, \mathrm{Mg}$ 含有 $\mathrm{PBS}, \mathrm{pH} 7.6$ （組
織培養用）とし，血球注度 $3 \%$ にして，本液 1 滴をツ反 応用注射器でスライド上に落とし，それに被検菌の栗粒 大の菌塊を白金耳で直接筧汼混合する（便法）と，原法 よりも簡便かつ明確に肉眼で $1 \sim 2$ 分以内に陰陽を判別 できる。

2）使用血球種はモルモットがよく，ウサギおよびウ マもニワトリと同等に使用でさる。ソメヨウ血球は使用 できないことはないが，ニワトリ血球より感受性がおと り適当ではなく，ウシ血球は最も感受性が鈍く使用でき ない。

3）被検菌はカンテン培地ないしクリグラー培地など の培養中に菌苔部培地面が酸性化しない培地に培養した ものを使用することが必要である。

4）エルトール菌の血球凝集作用は固有の性状である が，コレラ菌の非凝集性は不安定で継代保存中に SR 変 異に関係なく陽性化するものがある。

5) NAG ビブリオ，V. parahaemolyticus および $V$. alginolyticus には陰陽 2 型が認められる。

終りに御指導御校閲戴いた東邦大学教授桑原章吾博士 に厚く御礼申し上げますとともに，御鞭掅賜わつた横浜 検疫所三浦光所長ならびに検疫課長会田俊雄博士に感謝 し，血液を提供戴いた都食肉衛生検查所高橋義光博士な らびに菌株を分变賜わつた都衛研坂井千三博士，大石純 一博士また御協力戴いた横浜梌疫所横須賀支所長浜野满 雄博士に深剷します。

本論文の要旨は第 20 回日本細菌学会関東支部総会に 報告した。

\section{文 献}

1) Moor, C. E. de : A non-haemoltic ElTor vibrios as the cause of an outbreak of paracholera in West New-Guinea. The ElTor problem and pandemic paracholera in the West Pacific, Trop. Geograph. Med., 15 : 97, 1963.

2) Roy, C., S. Mukerjee \& S. J. W. Tanamal : Haemolytic and non-haemolytic ElTor vibrios. Ann. Biochem, Exp. Med., 23 : 553, 1963.

3）横浜検疫所：コレラ污染船舶 “Gunung Kerintji”" 終末報告费, 12 , 昭和 39 年 4 月.

4) Greig, E.D.W. : The haemolytic oction of Indian strains of cholera and cholera like vibrios, Indian J. Med. Res., $2: 623,1914$.

5) Burrows, W. \& R. Pollitzer : Laboratory diagnosis of cholera, Bull: Wld Hlth Org., $18: 275$ 1958.

6) Feeley, J. C. \& M. Pittman: Studies on the haemolytic activity of El Tor vibrios, Bull. Wld 
Hlth Org., 28 : 347, 1963.

7) Pollitzer, R. : Cholera, Wld Hlth Org., No. $43: 144,1959$.

8) Felsenfeld, O. : Present status of the ElTor vibrio problem, Bact. Rev., 28 : 72, 1964.

9) Mukerjee, S. : The bacteriophage susceptibility test in differentiating Vibrio cholerae and Vibrio eltor, Bull. Wld Hlth Org., 23 : 333, 1963

10) Gan, H. H. \& S. K. Tjia: A new method for the differentiation of $V$. comma and V. ElTor, Amr. J. Hyg., 77 : 184, 1963.

11) Finkelstein, R. A. \& S. Mukerjee: Hemagglutination; A rapid method for differentiating $V i$ brio cholera and ElTor vibrios, Proc. Soc. Exp. Biol. Med., 112 : 355, 1963.

12) Zinnaka, Y., S. Shimodori \& K. Takeya : Hemaggluating activity of Vibrio comma, Japan J. Microbiol., 8 : 97, 1964.

13) Rizvi, S., M. I. Huq \& A. S. Benenson: Isolation of hemagglutinative non-ElTor cholera vibrios, J. Bact., 89 : 910, 1965.

14) 阿部, 井上, 岩永, 片野, 池田, 長尾, 木村 : トリプ シンおよびポリミキシンBによるコレラ菌とエ ルトール菌の鑑別法に対する検討, 第 17 回日本 細菌学会関東支部例会口演, 1964 年 6 月.

15) 東京大学伝染病研究所: 細菌学実習提要, 丸善, 東京, 1958.

16) Barua, D. \& A. C. Mukerjee : Direct bacterial hæmagglutination test for differentiating ElTor vibrios from $V$. cholerae, Bull. Cal. Sch. Trop.
Med., 11 : 85, 1963.

17) Barua, D. \& A. C. Mukerjee: Haemagglutinating activity of ElTor vibrio and its nature, Indian J. Med. Res., 53 : 399, 1965.

18) Feeley, J.C. : Classification of Vibrio cholerae (Vibrio comma), including ElTor vibrios, by infrasubspecific characteristics, J. Bact. 89 : 665, 1965.

19）阿部久夫：コリスチンデスクによるコレラ菌と エルトール菌の鑑別, 日本細菌学雑誌, $20: 643$ 1965.

20) 木村正健：変法トリプシン培地によるエルトー ル菌とコレラ菌の鑑別, 日本細菌学雑誌, 21 : 19, 1966.

21) Kraus, R. \& S. Luding : Ueber Bakteriohämagglutinine, Out see copy und Antihämamagglatini, Wien Klin Wschr., 15 : 120, 1902

22) Fukuhara, Y. : Ueber hämagglutinierende Eigenschaften der Bakterien, Z. Imm. Forsch., 2 : 313, 1909.

23) Duguid, J. P., I. W. Smith, G. Dempster \& P. N. Edmonds: Non-flagellar filamentous appendages ("fimbriae") and haemagglutinating activity in Bacterium coli, J. Path. Bact., 72 : 397, 1957.

24) Duguid, J. P., \& R. R. Gillies: Fimbriae and adhesive properties in Dysentery bacilli, J. Path. Bact., 72 : 397, 1957.

25）中谷林一郎, 坂崎利一共訳 : 腸内細菌同定法, 一 成堂, 東京, 1964. 


\title{
Improved Techniques of Haemagglutination Test for the Differentiation of Vibrios
}

\author{
Masatake KIMURA \\ (Yokohama Quarantine Station)
}

Investigations on the improvements of the techniques of haemagglutination test for the differentiation of vibrios were made using strains of V. cholerae, V. eltor, NAG vibrio, V. parahaemolyticus and V. alginolyticus.

As the suspending medium of the red blood cells, PBS ( $\mathrm{pH} 7.6$, for tissue culture) was most excellent. One drop of $3 \%$ red blood cell suspension in PBS at pH 7.6 was placed on the glass slide, and sufficient amount of test organism (about $0.5 \mathrm{mg}$ ) was rubbed into the drop with the loop and mixed well; then, visible clumping took place almost immediately.

As for the species of the red blood cells, guinea pigs were most preferable; chick, rabbit and horse were next in order; sheep and ox were not found suitable.

Test organisms grown in the media in which acidification takes place after the bacterial growth should not be used for this test. V. eltor cells grown in such condition failed to cause positive clumping.

Barua and Mukerjee (1965) stated that red blood cells of guinea pigs are inadequate for this test, because of the occasional positive clumping in strains of $V$. cholerae. However, according to the results of this study, visible clumpings were also observed with red blood cells of the other species such as horse, rabbit and chick. Continued observation of the same strains of $V$. cholerae revealed that in some strains of $V$. cholerae haemag. gliutination test turned to positive during the course of subculture, indifferent to $S-R$ variation. 